\title{
Science to Support Aquatic Animal Healith
}

\section{Disease Ecology, Surveillance, and Development of Mitigation Strategies}

Healthy aquatic ecosystems are home to a diversity of plants, invertebrates, fish and wildlife. Aquatic animal populations face unprecedented threats to their health and survival from climate change, water shortages, habitat alteration, invasive species and environmental contaminants. These environmental stressors can directly impact the prevalence and severity of disease in aquatic populations. For example, periodic fish kills in the upper Chesapeake Bay Watershed are associated with many different opportunistic pathogens that proliferate in stressed fish populations. An estimated 80 percent of endangered juvenile Puget Sound steelhead trout die within two weeks of entering the marine environment, and a role for disease in these losses is being investigated. The introduction of viral hemorrhagic septicemia virus (VHSV) into the Great Lakes-a fishery worth an estimated 7 billion dollars annually - resulted in widespread fish die-offs and virus detections in 28 different fish species. Millions of dying sea stars along the west coast of North America have led to investigations into sea star wasting disease. U.S. Geological Survey (USGS) scientists are assisting managers with these issues through ecological investigations of aquatic animal diseases, field surveillance, and research to promote the development of mitigation strategies.

\section{What We Do}

USGS research supports the needs of regulatory agencies including U.S. Fish and Wildlife Service, National Park Service,

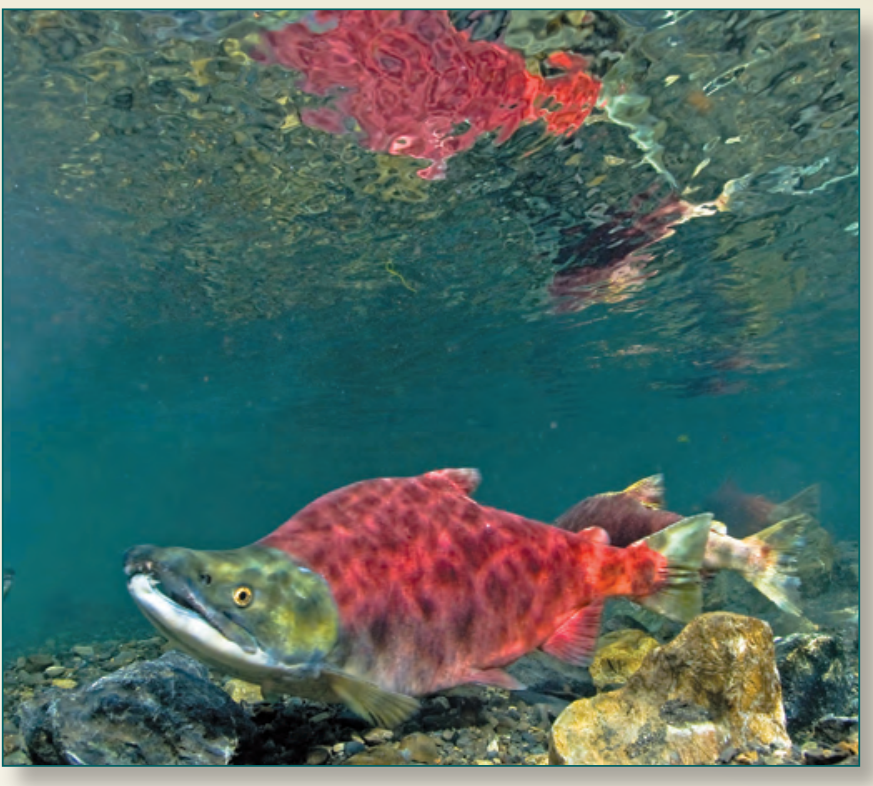

Western Fisheries Research Center - WFRC researchers used a virus genetic typing system to identify the source of the virus among free-ranging salmonids. This science was used by the U.S. Fish and Wildlife Service and U.S. Army Corps of Engineers to support redesign of the hatchery water supply system, and to monitor success of that change in dramatically reducing viral disease. U.S. Department of Agriculture, Bureau of Reclamation,

National Oceanic and Atmospheric Administration (NOAA), and numerous local, State, and Tribal agencies. USGS scientists support these organizations through a diverse research portfolio that often begins with on-the-ground disease surveillance, investigation of aquatic animal die-offs, and diagnostic support. Field investigations often lead to laboratory studies to identify cause of disease, evaluate risk factors, and develop disease detection and mitigation tools. Results from field and laboratory studies can be integrated into epidemiological models to understand disease transmission rates and population level disease impacts. The goal of USGS research is to identify science-based solutions that can restore aquatic ecosystems to favorable health and mitigate disease risks. Our science promotes global efforts to protect the aquatic ecosystems that connect continents.

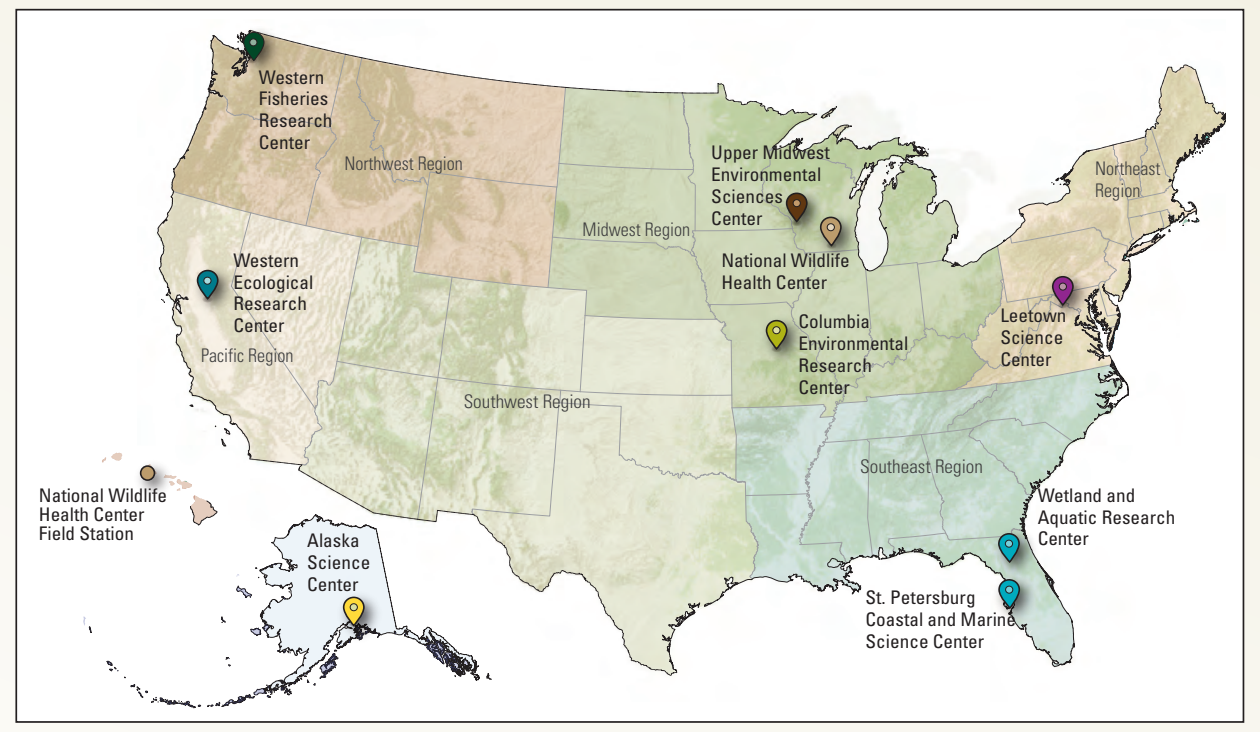

USGS science centers conducting aquatic animal health research are located throughout the country. 


\section{Why the USGS}

The U.S. Department of the Interior (DOI) manages one-fifth of the nation's lands, which includes a range of freshwater, estuarine and marine habitats. The DOI is charged with protecting the health of these aquatic resources while supporting their commercial, recreational, and cultural use. As the science agency of the DOI, USGS conducts research that informs management and conservation of aquatic resources. The USGS also provides other Federal, State and Tribal natural resource agencies with unbiased science and tools to support management decisions. Stewardship of the Nation's natural resources requires knowledge of ecosystem function and environmental stressors that impact these resources.

Scientific expertise in aquatic animal health within the USGS spans over eight science centers across the nation, with researchers working on all aspects of aquatic animal diseases. The Western Fisheries Research Center (WFRC) in Washington State has specialized facilities for safely conducting infectious disease trials in freshwater and marine fish, as well as an aquatic high containment laboratory for research on foreign aquatic animal diseases. The WFRC is the sole World Organization for Animal Health (OIE) reference laboratory for two important diseases of salmon and trout, infectious hematopoietic necrosis and bacterial kidney disease. The Leetown Science Center (LSC) has been leading efforts in the Chesapeake Bay and Great Lakes watersheds to assess the impact of emerging pathogens and environmental stressors including endocrine disrupting chemicals on aquatic animals in these critical aquatic ecosystems. Veterinary specialists at the National Wildlife Health Center-Honolulu Field Station are studying all aspects of a tumor disease that is the most common reason for green turtle stranding. Researchers at the St. Petersburg Coastal and Marine Science Center, as well as at the Honolulu Field Station, are conducting vital research to understand and mitigate environmental drivers of coral reef disease.

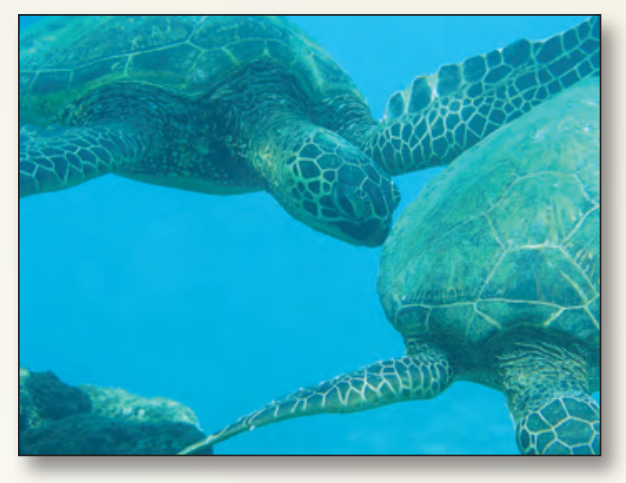

National Wildlife Health Center - Honolulu

Field Station - Scientists at the NWHC-HFS are collaborating with National 0 ceanic and Atmospheric Administration to understand causes of mortality in threatened green turtles (as shown in this image) in Hawaii and the Pacific, the State of Hawaii to investigate and manage causes of mortality in reef fish and echinoderms in Hawaii, and various partners to develop tools to understand coral reef health globally. Some HFS projects have led directly to management interventions. A recent example was removal of a shipwreck from Palmyra Atoll National Wildlife Refuge by U.S. Fish and Wildlife Service to mitigate impacts of invasive anemones on coral reefs.

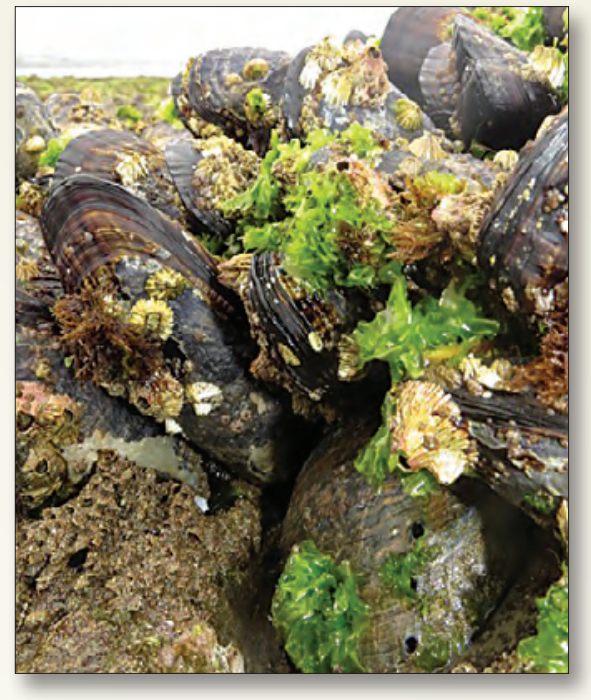

Western Ecological Research Center WERC research investigated the link between intertidal temperature variation and the impact of a devastating disease called "withering syndrome" on black abalone. Black abalone, the most endangered species along the California coastline, is now sparsely populating the coast with solitary abalone occasionally seen as in this image. This research highlights the importance of understanding the complexity linking climate and infectious disease.

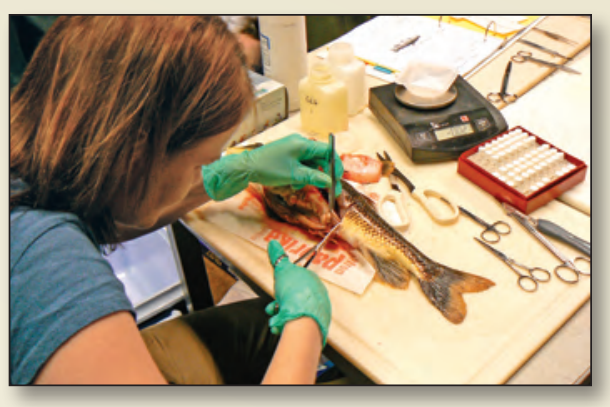

Leetown Science Center - Scientists at the LSC partner with U.S. Fish and Wildlife Service, U.S. Environmental Protection Agency, and various State agencies for infectious and non-infectious fish disease investigations. Here, a scientist collects liver samples from a wild-caught white sucker from the Milwaukee River. This research contributed to advancements in biomarker discovery, and gene expression profiling of resident fish species to augment traditional fish health assessment methodologies. It also led to the discovery of a novel hepatitis B-like virus-the first hepadnavirus known to infect cold-blooded organisms.

\section{USGS Web Links}

USGS National Wildlife Health Center http://www.nwhc.usgs.gov/

USGS Western Fisheries Research Center http://wfrc.usgs.gov/

USGS Leetown Science Center http://www.lsc.usgs.gov/

USGS Columbia Environmental Research Center http://www.cerc.usgs.gov/

USGS Western Ecological Science Center http://www.werc.usgs.gov/

USGS Upper Midwest Environmental Sciences Center http://www.umesc.usgs.gov/

USGS St Petersburg Coastal and Marine Science Center http://coastal.er.usgs.gov/

USGS Alaska Science Center http://alaska.usgs.gov/

USGS Wetland and Aquatic Research Center http://www.usgs.gov/centers/ wetland-and-aquatic-research-center-warc/

Authors:

Maureen K. Purcell and M. Camille Harris

For more information:

M. Camille Harris

USGS Wildlife Disease Coordinato

703-648-4019 mcharris@usgs.gov

Cynthia S. Kolar

Invasive Species Program Coordinator

703-648-4023 ckolar@usgs.gov

Publishing support provided by the U.S. Geological

Survey, Science Publishing Network,

Tacoma Publishing Service Center

Design: William Gibbs 